\title{
Despre literatură și ideologie în „Scânteia tineretului" - anul 1968
}

\author{
Prof. univ. dr. Nicoleta IFRIM \\ Centrul interdisciplinar de studii culturale central și sud-est europene, \\ Universitatea "Dunărea de Jos" din Galați
}

\begin{abstract}
Our study descriptively presents the main articles published in 'Scânteia tineretului' (1968) in order to grasp the ideological lines coordinating the literary production of the time.
\end{abstract}

Keywords: ideology, literature, programatic ideas, 'Scânteia tineretului'.

Publicație centrală a Uniunii Tineretului Comunist, „Scânteia tineretului" gazduiește, pe parcursul anului 1968, o serie de articole în care ideologia politică totalitară se oglindește vădit în direcție programatic-literară, dirijând construcția ideologică a literaturii vremii. Prezentăm, în continuare, principalele articole publicate, cu intenția declarată de a structura un tablou descriptiv care va surprinde metamorfozele doctrinare stereotipe ale discursului critic și literar al anului în discuție.

Ștefan Bănulescu scrie, în „Scânteia tineretului” din 17 ianuarie, despre Anonimatul premiilor literare: „Chiar târzii, datele decernării premiilor nu sunt cunoscute precis, pot fi la începutul sau la sfârșitul lui februarie, în martie, uneori în aprilie. Dacă datele întârzie în imprecizie, pot da sentimentul că premiile se acordă pentru a fi acordate totuși, sensul lor riscând să se piardă între dubiu și formalitate. E un adevăr banal că premiul literar nu privește numai o carte sau un autor. Relația cu gradul de intensitate sau cu acalmia fenomenului literar, cu competiția febrilă a editurilor în selecția de autori și cărți sau, dimpotrivă, cu uniformitatea editorială, relația cu opiniile critice calde încă și cu ambiția de identitate și de atitudine a revistelor - sunt lucruri pe care un premiu literar le poate reprezenta mai bine când e decernat la timp, constituind pentru anul literar respectiv un reper de existență specifică, un punct nodal al datelor interioare de viață cultural-literară." (Nr. 5802, miercuri, 17 ianuarie) Nicolae Dragoș anunță, în 24 ianuarie, rubrica Poezia-univers deschis, în care cronicarii literari ai ziarului, C.Stănescu și M.Ungheanu, vor „recomanda în succinte prezentări acele volume de poezie pe care le consideră în primul rând demne de atenția lectorului, având în vedere forța emoțională pe care o însumează, distincția unei autentice voci lirice, noutatea investigațiilor poetice și 
a roadelor acestora, originalitatea limbajului și măsura în care acesta se supune sau este dominat de sentimente, cantitatea de frumusețe și gânduri nobile purtate cu o generoasă dăruire de la creator spre cititor. (...) Desigur, din inconveniențe de spațiu, nu au putut fi integrate în acest ghid volumele Monolog din Babilon (Al.Philippide), Elegie pentru floarea secerată (Eugen Jebeleanu), Parabola focului (V.Nicolescu), Oul și sfera (Nichita Stănescu), Iadeș (Dumitru M.Ion), Sfera gânditoare (Gr.Hagiu) - volume care nu pot lipsi orientării lecturii poetice." Volumele recenzate de C.Stănescu și M.Ungheanu sunt: Poeme, de Marin Sorescu („,Comentariile unei critici superficiale clasase deja pe Sorescu între parodiști și autorul pare a-și renega debutul. Poeme în colecția Albatros dovedesc indiscutabil un poet autentic și particular; ceea ce nu s-a sesizat încă suficient este gravitatea versurilor lui Marin Sorescu, calitatea reflecției ascunsă sub o superficie de ironie sau amuzament"), Ochiul cel mare, al Angelei Croitoru („imnuri ale creației, naturii, soarelui, simțurilor. Poeziile se dezvoltă în înălțime, au ceva sacerdotal în ele și invită la cult”), Țărâna serilor, de Teohar Mihadaş („,Social și profund ancorat într-un sol autohton este poetul nu prin teme - care-și au și ele, firește, importanța lor - dar mai cu seamă prin arderea sa în cenușa mitică a nobililor înaintași cărora, ca într-un cimitir miraculos animat, le retrăiește existența desprinsă de lut”), Versuri, de Leonid Dimov („Admirabil animator de naturi moarte, L.Dimov exprimă prin prea alesul său gust și o criză autentică a materiei vii a poeziei, o abolire a pastei și pastelului, a naturii însăși, atotinspiratoare"), Patruzeci și șase poezii de dragoste, de Gheorghe Tomozei (poetul „evocă numai - e o precizare nu și o subapreciere - emoția originară a cuvintelor, recreează misterul iubirii fără a-l fi creat"), Destine paralele, a Ninei Cassian (volumul conține „o astfel de poezie în care se mediteazăasupra unui destin comun, firesc, și a altuia monstruos care ar reprezenta destinul creatorului de geniu”), Poziția aștrilor, de Dan Laurențiu (cartea „refuză orice indicație a epicului, a anecdoticului, a poantei. Lirismul e căutat firesc în stări”), Seminția lui Laokoon, de Ștefan Aug.Doinaș (tema „predilectă a poetului a rămas aceea, inepuizabilă, a perceperii timpului, înregistrat cu veșnica melancolie a spiritelor calme, care și-au fortificat cu calm pietros interiorul." (Nr. 5808, miercuri, 24 ianuarie)

În secțiunea Despre cărțile de proză ale anului 1967 din 1 februarie, C.Stănescu și M.Ungheanu prezintă Moromeții vol.II (,Marin Preda analizează marile transformări sociale în lumea satului de după război. (...) Ceea ce aduce nou prozatorul e un ochi mai accentuat satiric"), Francisca, ediția a II-a, a lui Nicolae Breban („Reeditarea Francescăi e destinată să întărească valoarea unui debut de o forță puțin comună. Cunoscut sumar și inconcludent, din câteva 
nuvele sau fragmente epice publicate sporadic, Nicolae Breban a ținut să ne facă surpriza unei demonstrații scriitoricești pe care puțini și-o asumă. Francisca este romanul unor ființe extraordinare”), Vară buimacă, de Fănuș Neagu („Scriitorul se detașează, în acest volum, pe cât îi stă deocamdata în putință, de materia prozei sale care, privită cu atenție, nu mai poate părea atât de zonală, folclorică, rustică, pitorească etc. Vrem să spunem că scriitorul este mult mai preocupat de atitudinea față de materia epicii sale, creatorul începe să-și perceapă creația ca pe o realitate care nu-i mai aparține"), Cordovanii, ediția a II- $a$, de Ion Lăncrăjan (un „masiv roman al cooperativizării”, „aspectul rezistent al cărții este în mimarea psihologiei țărănești cuprinsă în momentele de divulgare a sa"), Reconstituirea, de Horia Pătrașcu („,autorul simbolizează o rară categorie de scriitori, conștienți de puterile lor, în stare să scoată tot ce se poate din subiectele convenabile lor"), Frig, de Dumitru Țepeneag („e un autor păcălit de personaje, un creator căruia creația îi joacă neîncetat farse. În fond chinul de a organiza e subminat permanent de legile oscure ale hazardului distrugător. Nici vorbă de univers oniric, de o lume a visului căreia autorul să-i fi găsit principiul arhitectonic. Scriitorul organizează în permanență înscenări având aerul că i se întâmplă lucruri extraordinare"), Sufereau împreună, ediția a II-a, de Ion Băieșu („epica pură exprimă interesul pentru fapt și este înclinată să dea prioritate anecdoticului în care personajele se pierd, Băieșu deține calitatea evidentă de ași urmări cu sagacitate personajele, cu un fel de răutate de autor satiric, care are mereu ceva de plătit, de răzbunat etc.") și Drumuri și răspântii, de M.R.Paraschivescu („,o autentică carte de reportaje, dovadă a unei conștiințe intelectuale exemplare. Într-o vreme în care reportajul a intrat într-un con de penumbră, mai ales cel de atitudine, exemplul unor publiciști care nu s-au sfiint în momente hotărâtoare să facă reportaj la zi, reportaj de atitudine, este binevenit.") (Nr. 5815, joi, 1 februarie). Ștefan Aug.Doinaș scrie despre Cum trebuie citită poezia modernă: „Mai întâi, poezia modernă este dificilă. Hermetismul ei, care se datorește fie unei obscurități genuine a lirismului, fie unei încifrări a expresiei (pentru că există poezie dificilă și poezie obscură!) pretinde din partea cititorului un îndelung antrenament intelectual. (...) Poezia modernă este, apoi, intelectualistă: ea nu mai exprimă sentimentele tradiționale ale poeziei tradiționale. (...) E o poezie care solicită intelectul și imaginația și nu o poezie care stârnește afectivitatea noastră. (...) În al treilea rând, poezia modernă e o poezie a ambiguității: sensul discursului liric nu e niciodată precis, univoc, limpede; întotdeuna o poezie modernă este interpretabilă. (...) Poezia modernă respinge uneori prozodia tradițională (rimă, ritm, forme fixe, metrică etc.), practicând versul alb sau liber. De ce? Pentru că unii poeți moderni se simt 
încorsetați în forme-poezii tradiționale, frânați în elanul lor, obligați la combinații de cuvinte irelevante." (Nr. 5818, duminică, 4 februarie)

C.Stănescu recenzează, în numărul din 29 februarie, volumul de versuri al lui Ion Bănuță, Olimpul diavolului, pornind, în demersul său, de la opiniile favorabile ale unor figuri critice remarcabile (G.Călinescu, Argezi, Perpessicius), dar punctând, în esență, „vocația contradictorie” a poetului: „Critici cu o foarte mare bună credință au crezut (!) o clipă în ceea ce li s-a părut a fi Ion Bănuță. Nu pot fi, în nici un caz, învinuiți de subiectivism. Singurul vinovat este chiar poetul ale cărui volume nu sunt decât planuri abandonate. Ele rămân numai ca semne neconvergente ale unei ambiții puțin obișnuite. (...) În ceea ce-l privește pe Ion Bănuță, vom spune că lirismul primar - valabil esteticește - se teatralizează alături de masca pe care ar fi putut să o încapă. Poetul, dintr-un exces produs de spaimă, ne arată pe rând masca și teatrul, Dumnezeul și Diavolul. Dar poezia nu e în instrumente, ci în deplina ei unitate, în simultaneitatea lor. Dumnezeu este chiar Diavolul. Poetul îi creează pe rând pentru că nu-l mai conține pe nici unul." Articolul este continuat cu un Post Scriptum, în care C.Stănescu critică recenzia lui Virgil Ardeleanu (publicată în Steaua nr.1/1968) facută volumului II al Moromeților: „Nu putem, firește, avea nimic cu credința cronicarului că se află în fața unei opere slabe. (...) Trebuie, în fine, să mai recunoștem consecvența criticului cu nobila sa obsesie, căci ce s-ar fi întâmplat dacă Moromeții vol.II nu era un roman schematic?! (...) Schematic vorbind, ca să rămânem la modalitatea cronicarului, avem de-a face cu un roman despre țărani, despre cooperativizare, despre împotrivirea subtilă a elementelor chiaburești etc. etc., adică un roman care ne evocă nouă azi tot cortegiul de scheme și clișee de până la el! Confuzia produsă de transferul unor obsesii ale criticului asupra romanului discutat este, deci, o eroare scuzabilă." (Nr. 5840, joi, 29 februarie)

"Scânteia tineretului" din 12 martie publică o pagină de discuții ale literaților contemporani despre Piesa istorică. Un sector dramaturgic de mari resurse, la care participă Horia Lovinescu, Al.Paleologu, Paul Anghel și Al.Voitin. Punctul de plecare al discuțiilor este reprezentat de „apariția în ultima vreme a unor foarte interesante lucrări cu subiect istoric" care „oferă niște repere solide perspectivei asupra unui întreg sector din dramaturgia noastră. Factura foarte diferită a lucrărilor la care ne referim în primul rând (Petru Rareș de Horia Lovinescu, Săptămâna patimilor de Paul Anghel, Procesul Horia de Al.Voitin), relația - mult diferită de la un autor la altul - cu istoria, cu evenimentele și documentele ei, finalitatea diversă a operațiilor artistice dovedesc neomogenitate fundamentală a dramaturgiei istorice." În acest sens, 
Al.Paleologu afirmă că „Petru Rareş nu relatează evenimente, nu înscenează fragmente de cronici. E o meditație asupra puterii, asupra raporturilor dintre destinul individual și istorie. Ficțiunea primează." Pentru Horia Lovinescu, „misiunea piesei istorice nu este să refacă evenimentele. (...) Model pentru piesa istorică nu cred că poate fi decât Shakespeare. (...) Două lucruri m-au interesat în această piesă: să conturez un destin istoric anume, propriu acestor locuri, care deci depășește limitele unei epoci și să realizez un tip de conducător care mi se pare caracteristic pentru poporul și istoria noastră, dar care e totodată o personalitate suficient de bogată pentru a fi reprezentativă pentru problematica puterii." Paul Anghel notează că „literatura istorică este, sau poate deveni, o asemenea modalitate, întâlnindu-se astfel cu reportajul și memorialistica." La rândul său, Al.Voitin notează faptul că „Piesa proces poete constitui o direcție foarte interesantă pentru că ea sintetizează raportul dintre poziții, opune foarte clar ideile. (...) În Procesul Horia am intenţionat să realizez acest gen de conflict pe care-l consider cel mai bogat în sensuri dramatice, chiar tragice, și cel mai adecvat unei înțelegeri în adâncime a istoriei." (Nr. 5850, marți, 12 martie)

M.Ungheanu semnează articolul Oboseala reportajului a sterilizat proza?, în care constată că „O proză cu problematică interesantă s-a născut din acestă acumulare de date. Trecând de la reportaj la nuvelă sau roman atât Petru Vintilă cât și Nicolae Țic, Radu Cosașu sau Pop Simion au avut avantajul contactului cu un material de viață încărcat de semnificații, proza lor clădită pe experiența reportajului fiind vie de atât timp cât purta un viu contact cu febrilitatea acestuia. (...) Proza noastră are nevoie de confruntarea cu aerul proaspăt al reportajului. (...) O revitalizare, în aceste condiții, a reportajului în funcțiile sale plenare ar ajuta, credem, și procesul de orientare a prozei spre problemele actualității." (Nr. 5866, sâmbătă, 30 martie) Același M.Ungheanu publică, în 4 mai, articolul Diversitatea cultivării clasicilor, în care consemnează: „În afara monografiei totale și a ediției de referință, pietre de încercare pentru oricare critic și istoric literar, în felul cum tratăm clasicii are o însemnătate esențială modalitatea comentării lor. O monografie nu poate rezolva niciodată chestiunea interpretării unui clasic, cu excepția cazurilor de excepție și pluralitatea de opinii în jurul operelor și autorilor de răsunet este binevenită. (...) Comoditatea editorială care consideră că a rezolvat problema reconsiderării clasicilor, tipărind câte o monografie despre un scriitor, nu paote fi acceptată. (...) Mobilitatea eseului e mult mai utilă longevității clasicilor decât înțepenitele monografii adeseori greu de parcurs și de multe ori e preferabil un eseu ca cel despre Liviu Rebreanu scris de Lucian Raicu decât o anostă monografie." (Nr. 5894, sâmbătă, 4 mai) 
Gheorghe Suciu publică, în numărul din 11 mai, articolul Se poate planifica și organiza mai bine trecutul artei? în care indică nevoia de sistematizare critică, deoarece „literatura noastră nu-i încă satisfăcător organizată. (...) Sumar vorbind, o literatură e bine organizată când folosește chibzuit următoarele trei mijloace:-editarea și reeditarea; -antologia; -istoria literară. Cum nu avem până la ora actuală nici un autor complet editat, va trebui ca în prima etapă să se stabilească cel puțin o listă de douăzeci sau treizeci de autori pe care în decurs de zece ani, să zicem, să-i avem integrali în bibliotecile noastre personale. (...) $\mathrm{Nu}$ avem o antologie a nuvelei românești, a schiței, a sonetului, a eseului, a comediei, a absurdului folcloric și a celui cult, a unei teme literare, a discursului oratoric, a articolului de presă făcut de artiști, a cronicii literare etc. (...) O istorie literară e o tentativă, preconcepția oricât de lucidă ar fi nu scutește autorul de peripeții și enigme (...). O istorie literară e o operă care presupune foarte mult risc. De altfel Istoria lui Călinescu a întâmpinat la apariție cele mai vehemente critici și oare nu mai întâmpină și astăzi căci altfel ce ar explica nereeditarea ei atât de mult dorită?" (Nr. 5900, sâmbătă, 11 mai)

C.Stănescu recenzează, în „Scânteia tineretului" din 27 iunie, romanul lui Marin Preda, Intrusul, care propune "tema lui Moromete, tema lui Marin Preda. (...) Marin Preda este preocupat de ideea rezistenței și dizolvării unei personalități.(...) S-ar părea că aspectul tragic este mutilarea și înstrăinarea eroului, neputința lui de a rămâne în orașul întemeiat. (...) Sensul moral și chiar moralizator de bună calitate este clar. Marin Preda își sacrifică eroul pentru a face acest sens cât mai convingător." (Nr. 5940, joi, 27 iunie)

Laurențiu Ulici prezintă, în 11 iulie, volumul lui Basarab Nicolescu, Ion Barbu. Cosmologia "Jocului secund”, remarcând faptul că „Paralela matematică poezie nu e scopul lucrării lui Basarab Nicolescu, cum lăsau să se creadă unele cronici apărute în presa literară, ci mijlocul, modalitatea de figurare estetică a universului poeziei lui Ion Barbu. (...) Poezia este desfăcută din nodurile ei formale, într-un fel limpezită, până la semnificațiile pure care-i vor lumina lirismul. Între spirit și afect, între rațiune și sensibilitate există o sinteză și pe această sinteză, mereu reclamând-o, stă întregul univers, conturat unitar în Joc secund. Momentele ei de realizare, perioadele de salt spre închegarea supremă, sunt ordonate în trei mituri esențiale: mitul oglinzii, al Nunții și al Soarelui. Cunoașterea poetică le presupune în particularitatea lor dar mai ales, prin alăturare, în unitatea lor semnificantă." (Nr. 5952, joi, 11 iulie)

În 18 iulie, este publicată ancheta Pentru cine scrii? Pentru ce scrii? la care participă Iulian Neacșu (Responsabilitatea scriitorului - „Fără a înceta să reprezinte o aspirație universală, scriitorul este determinat de existența sa 
istorică și socială”), A.I.Zăinescu (Fără adresă? - „nu cred că scrie nimeni în zadar, fără adresă, fără cauză, fără a-și pune problema rostului său cu atât mai mult cu cât avem în spate dacă nu o îndelungă tradiție a scrisului românesc, cel puțin o oralitate a lui exemplară, cu atât mai mult cu cât nota distinctă a fiecăruia se câștigă deja greu în concertul pe atâtea voci și instrumente la care asistăm”) și Grigore Arbore (Condiția filozofică a literaturii - „Literatura devine nu arareori factor adiacent filozofiei, sisteme și teorii ghicindu-se în substratul multor opere. $\mathrm{Nu}$ arareori deducem un întreg sistem de gândire din opere literare de anvergură.") (Nr. 5958, joi, 18 iulie)

În numărul din 27 iulie, secțiunea Pentru cine scrii? Pentru ce scrii? găzduiește tema Responsabilității scriitorului. În acest context, Nichita Stănescu discută despre Scriitorul - între prezent și viitor, considerând că „scriitorul este cronicarul vremii lui, placa sensibilă fotografică a vremii lui, urma de talpă apăsată în pământul prezentului, înregistrând viitorul. (...) Scriitorul este cel care are ceva de spus, dar nu toți cei care au ceva de spus izbutesc să și spună; a izbuti să spui ceea ce vrei să spui, adevărul tău individual și cunoscut de tine însuți, necunoscuților din prezent și din viitor constituie sensul și râvna perpetuă a miraculosului mod de existență pe care-l numim poezie și care constituie una dintre dimensiunile noastre, fie că o producem, fie că o receptăm." Pentru Alexandru Ivasiuc, Literatura - mod de acțiune aduce în primplan „forța socială deosebită a literaturii, pentru că ea potențează mereu omul uman, adică omul social, depășind mereu individualitatea îngustă, menține mereu proaspete valorile fundamentale, naște mereu noi valori rezultate ale interacțiunii noastre cu lumea, necesară continuei în-fiinţări căreia îi suntem sortiți." Florin Mugur scrie despre Puterea de a te regenera pentru oameni, notând faptul că „poeții sunt niște oameni care înfăptuiesc cea mai frumoasă lucrare cu putință: încearcă să îndepărteze din cugetul muritorilor tot ce este urât și întunecat, încearcă să-i transforme în oameni noi - superbă, rămâne superbă această formulă banalizată care vorbește despre lucruri sfinte; despre puterea de a te regenera, despre autodepășire, despre încercarea extraordinară a comunismului de a-i obliga pe oameni să-și câștige în sfârșit condiția umană." La rândul său, Fănuș Neagu declară că Scriu cu gândul la neamul meu adâns și demn, „scriu nu cu gândul la glorie, ci la datorie, la neamul meu adânc și demn și neclătinat de toate durerile care 1-au mușcat." Constanța Buzea vorbește despre Respectul cuvintelor despre om, declarând că „scriu pentru că aceasta este singura mea șansă de a fi." (Nr. 5966, sâmbătă, 27 iulie)

În „Scânteia tineretului” din 30 iulie, C.Stănescu prezintă Istoria literaturii române (compendiu), a lui G.Călinescu, sub titlul Viața literaturii și literatura vieții, 
constatând că „Mitul lipsei de vechime este spulberat printr-o adevărată reinventare a scriitorilor ieșiți din matca spirituală a unui popor îndeajuns elaborată și consolidată ca să susțină această darmatică existență (coexistență) a literaturii. (...) Călinescu creează existența de fapt a literaturii, făcând să vibreze substanțial o enormă sumă de posibilități. Semnificația actului său creator este, în ordinea urgențelor, una profund patriotică. (...) Rațiunea criticului, stimulată de o cultură de un dinamism fără precedent, produce adevărata viață a literaturii. Caracterul raționalist al operei lui Călinescu este convingător și evident. (...) Criticul acordă scriitorilor un tratament organic, scos din structura lor adâncă de exponenți ai spiritualității românești." (Nr. 5968, marți, 30 iulie)

Numărul din 31 iulie publică interviul acordat de Eugen Simion Smarandei Jelescu pe tema Literaturii tinere. Criticul afirmă că „În jurul anului 1966, când poezia română trecea printr-un moment de criză, criza limbajului poetic, s-a constituit limpede această generație, anunțată, de fapt, cu mult înainte, de Nicolae Labiș. Consider că Labiș nu este numai un poet de valoare politică, ci este și un liric ce trăiește estetic prin substanța lui. Mi se pare o nededreaptă eroare de a-1 contesta. (...) Eu cred din adâncul sufletului că Nichita Stănescu este un mare poet. Vă amintesc, de altfel, uitând o secundă de modestie, că articolul meu de debut din Contemporanul, acum ani, îi era dedicat. Spuneam atunci, și spun și astăzi, că este cel mai bun poet al generației sale. (...) Timpurile moderne ale prozei românești cunosc în orice caz un mare prozator, el se numește Marin Preda. (...) Nicolae Breban și al.Ivasiuc vor să împingă proza într-o direcție care-i lipsește, a unei mai profunde investigații pe verticală. Trebuie amintită de asemenea extraordinara forță epică a lui Fănuș Neagu (...). Nu uit proza fantastică, un fantastic modern, aș spune neliniștit, cel din Iarna bărbaților, de Ștefan Bănulescu. Nici pe subtilul ironist caragealescul Nicolae Velea, nici fantasticul oniric al lui Dumitru Țepeneag, sau inteligența parabolică a lui Iulian Neacșu. (...) În afară de cei cunoscuți, notez din cea mai tânără generație pe talentații critici Valeriu Cristea, Mihai Ungheanu, Magdalena Popescu." (Nr. 5969, miercuri, 31 iulie)

Șerban Cioculescu scrie, în "Scânteia tineretului" din 5 septembrie, despre $O$ generație de scriitori militanți, afirmând că „pașoptiștii aveau o înaltă conștiință europeană, iar când afirmau că privirea Europei este țintită asupra noastră, ei rosteau o altă vorbă fecundă de anticipație, smulgându-ne inerției meridianului geografic și integrându-ne civilizației înaintate." (Nr. 6001, joi, 5 septembrie) Valentin Silvestru scrie, în „Scânteia tineretului” din 17 septembrie, despre Dramaturgia în contextul literar actual: „Este adevărat că unele scrieri dramatice mai noi, deosebite față de piesele vechi, refuzând schemele de 
construcție statornicite, exprimându-se într-un limbaj mai criptic, prezintă, inițial, pentru unele cercuri de spectatori oarecari dificultăți de percepție. (...) Cititorul, spectatorul vor avea a se familiariza (...) și cu moduri noi de cuprindere a realității și de cercetare a vieții lăuntrice a omului, propuse de literatură și deci și de dramaturgie." (Nr. 6011, marți, 17 septembrie)

Petru Popescu glosează, în 4 octombrie, despre Orizontul cultural al tânărului scriitor, remarcând că „există unele condiții care au ca efect dezorientarea tânărului scriitor, alterarea judecății lui estetice, lipsa de siguranță a gustului lui. Mulți scriitori tineri se nasc în familii rurale, dar sosesc foarte curând la oraș, unde încep să se bucure de tot ce este caracteristic vieții citadine. Cărțile lor continuă însă să reproducă, și chiar să exalte, realități țărănești, de care uneori autorii s-au despărțit cu ani în urmă și la o prea fragedă vârstă ca să nu le fi putut considera cu un ochi definitiv. Căpătăm astfel tot felul de cărți care au ca decor natural ruralitatea, dar care nu conțin adevăruri (nici eterne, nici circumstanțiale) despre ruralitate (...), ci cel mult metafore, talent prea puține idei, multe promisiuni, deseori neîmplinite. (...) Un alt lucru care mi se pare important este că dintre criticii literari prea mulți sunt cei care nu au o reală conștiință profesională, care nu știu să fie directori de conștiință, care nu și-au clarificat propria programă estetică, când nu sunt (căci și asta se întâmplă) lipsiți de adevăratul program teoretic. (...) Toate acestea ne pot face să spunem că cel puțin în clipa de față, mijloacele care să asigure accesul tânărului creator la multiplele izvoare ale culturii sunt încă insuficient prospectate și utilizate." (Nr. 6026, vineri, 4 octombrie)

Mihai Beniuc scrie, în 8 octombrie, despre Cititor și scriitor, în urma finalizării anchetei Pentru cine scrii? Pentru ce scrii?, punctând „răspunderea socială" pe care o are fiecare autor „când se prezintă prin scrisul său în fața publicului. (...) Căci scriitorul în ordinea spirituală este un creator de bunuri de uz obștesc. (...) Mai e nevoie să spun că a fi scriitor în România de azi a socialismului și a statornicei lupte pentru pacea popoarelor înseamnă să scoată apă vie pentru cei ce azi o caută, s-o scoți fie și din piatră seacă?" (Nr. 6029, marți, 8 octombrie)

„Scânteia tineretului" din 13 octombrie propune o dezbatere despre Receptarea literaturii, la care iau parte Nichita Stănescu (Avem nevoie de cititori talentați! - „Un cititor talentat este un cititor pasionat, un cititor pentru care lectura nu constituie un prilej de a-și pierde timpul, ci unul de a și-l spori $\mathrm{cu}$ timpul operei literare parcurse."), Cezar Baltag (Să avem sentimentul literaturii „Literatura de calitate nu este făcută pentru spiritele mediocre, călduțe, mic burgheze. Dragostea pentru artă presupune generozitate, dăruire, calități 
umane superioare."), Adrian Păunescu (Poeții sunt ceasuri ultrasensibile „Trebuie să ne iubim scriitorii cu sentimentul că ne iubim istoria.") și Mihai Ungheanu (Dificultatea nu înseamnă inacesibilitate - „Un produs artistic nu paote fi inaccesibil prin chiar condiția sa. Astfel, inaccesibilitatea ar fi o condamnare și ar exclude presupusa operă de la o competiție a valorilor, care nu se poate presupune decât în condițiile accesibilității.") (Nr. 6033, sâmbătă, 13 octombrie)

Petru Popescu scrie, în 23 octombrie, despre Prozatorul critic: „Câțiva prozatori cu capacitate teoretică reală avem, câțiva critici au ieșit din carapacea spiritului critic intrând în proză (notez ca deosebite realizări nuvelele și romanul lui Paul Georgescu și paginile de roman filozofic publicate acum mai multe luni de Matei Călinescu). Dar de aici pînă la desființarea efectivă a acestor granițe, până la dispariția complexelor de specialitate, care dau naștere la comportări speciale și viciază exprimările, până la liberul joc de idei al unor creatori care gândesc unii lângă alții și unii pentru alții, mai e un, cred, drum lung." (Nr. 6042, miercuri, 23 octombrie)

"Scânteia tineretului" din 25 octombrie publică dialogul dintre Iulian Neacșu și Dumitru Țepeneag pe tema traducerilor, față de care Țepeneag își devoalează poziția: „Traducerea nu poate fi considerată, stricto sensu, o operă de creație. Și totuși, munca traducătorului, activitatea lui îi oferă satisfacții mai mari decât să zicem, dezlegarea unei probleme de șah sau chiar de matematică. Câteodată, această satisfacție o egalează pe aceea a creației propriu-zise. Iar asta nu numai pentru că datorită eforturilor tale o operă de artă, realizată într-o altă limbă, pur și simplu se naște în limba în care o traduci; traducătorul nu-i doar o moașă literară, deși e și asta. Și nici comparația cu fotograful care developează clișeele clienților nu este suficientă. Ar fi o judecată superficială, utilitară și făcută din afară." (Nr. 6044, vineri, 25 octombrie)

În 2 noiembrie, Gheorghe Grigurcu scrie despre Literatura - portret al patriei: „Nu poate fi contestat faptul că operele literare iau naștere într-un mediu social-istoric determinat. O elementară apreciere a lor necesită o situare în timp și în spațiu, pe coordonatele cele mai simple și mai firești ale percepției oricărui act uman. Literatura română poartă acest nume pentru că s-a zămislit și se zămislește în spațiul patriei noastre, ca expresie a sufletului poporului român. (...) Fiecare literatură este mărturia unui popor, după cum fiecare popor este într-o proiecție absolută mărturia unei literaturi. (...) Valoarea literară autentică include în sine, așa cum s-a arătat din diverse puncte de vedere, nota apartenenței naționale. Ea crește pe solul unor realități de cultură și civilizație străvechi, continuându-le în registrul istoric al fiecărei epoci, dezvoltându-le, îmbogățindu-le, contribuind la limpezirea lor în lumina mișcătoare a spiritului." 
În același număr, Vintilă Ivănceanu glosează despre Scriitorul clasic și cititorul modern: „Reluând întrebarea pusă: cum citim clasicii? reiau și propunerea adresată ziarelor, revistelor, editurilor: o preocupare sporită și eficace pentru a-1 învăța pe cititorul modern cum să-1 citească pe autorul clasic. Astfel, prin asigurarea unui gust public complet, prin participarea lui la fluxul neîntrerupt al culturii noastre, aceasta va fi în măsură să-și mărească și forța de compresie și nobila capacitate de explozie." (Nr. 6051, sâmbătă, 2 noiembrie)

În 11 noiembrie, Mihai Beniuc scrie despre Supremația realității, notând faptul că „sscriitorul este o conștiință care se confruntă cu conștiințe; dar a sa cu precădere este chemată să le însume pe celelalte și să le despice în registrul lor multicolor”, iar Florența Albu glosează despre Conștiința răspunderii: „Dincolo de discuțiile sterile care s-au grăbit să emită prea timpurii judecăți de valoare în privința unui fenomen sau altul, din lirica sau proza contemporană, bilanțul adunării scriitorilor va fi demn de perioada istorică prin care trece poporul nostru, sub conducerea Partidului Comunist Român." ( Nr. 6058, luni, 11 noiembrie)

În numărul din 28 noiembrie, C.Stănescu recenzează romanul lui Nicolae Breban, Animale bolnave, în care scriitorul „face mai evidentă decât în romanul cu care debuta, Francesca, o vocație excepțională pentru personajul de forță, insul dotat cu o putere ieșită din comun și căreia se pare că uneori el însuși nu-i poate rezista. Forța lor neobișnuită și capabilă de mari sacrificii, dar și de mari orori stă în caracterul dramatic al destinului ce-i guvernează, un destin care le comandă actele și împotriva căruia nu se pot situa." (Nr. 6073, joi, 28 noiembrie).

Această prezentare strict descriptivă a articolelor publicate în „Scânteia tineretului" a anului 1968 va fi inclusă, în formă revizuită și adăugită, în volumul care urmează a fi publicat din Cronologia vieții literare românești. Perioada postbelică, anul 1968 (coordonare generală şi prefaţă - Acad. Eugen Simion; coordonator redacțional al ediției - Lucian Chișu) la Editura Muzeul Naţional al Literaturii Române.

\section{Bibliografie:}

Antofi, Simona, The Exile Literature of Memoirs - Debates, Dilemmas, Representative Texts and their Formative-Educative Effects, în Procedia - Social and Behavioral Sciences, Volume 93, 21 October 2013, Pages 29-34, ISSN: 1877-0428, WOS:000342763100005.

Cenac Oana, Discurs ideologic în "Ateneu" 1965, Actele conferinței internaţionale Lexic comun / Lexic specializat. Democratizarea cunoașterii" sau migrația lexicului specializat spre lexicul comun, ediția a X-a, Universitatea „Dunărea de Jos” din 
Galați, Facultatea de Litere, Centrul de Cercetare Comunicare interculturală și literatură, 19 - 20 mai 2017, publicată în Analele Universității „Dunărea de Jos” din Galați, Fascicula XXIV Lexic comun / lexic specializat, revistă indexată in bazele de date internaționale EBSCO: https://www.ebscohost.com/titleLists/cmscoverage.pdf, MLA (Modern Language Association, New York, www.mla.org) MLA International Bibliography \& Directory of Periodicals, CEEOL și Fabula. La recherche en littérature (www.fabula.org), anul X, nr. 2(18) /2017, Editura Casa Cărții de Ştiință, Cluj-Napoca, 2017, ISSN 1844-9476, p. 31-48.

Cenac Oana, General aspects of current political terminology, în Lexic politic - discurs politic, 2014, p.124-130, ISBN:978-606-17-0633-4, WOS: 000378358200007. Scânteia tineretului, 1968. 